\title{
Bridge over troubled water: managing compatibility and conflict among thought collectives in sustainability science
}

\author{
Niko Soininen ${ }^{1,14}\left(\right.$ Christopher M. Raymond ${ }^{2,3,4,10,15} \cdot$ Hanna Tuomisto ${ }^{3,10,16} \cdot$ Laura Ruotsalainen $^{5,10}$. \\ Henrik Thorén ${ }^{6} \cdot$ Andra-loana Horcea-Milcu $^{7}$ Milutin Stojanovic ${ }^{8,10} \cdot$ Sanna Lehtinen $^{9,10} \cdot$ Rachel Mazac $^{4,10}$. \\ Carlos Lamuela $^{10}$. Noora Korpelainen ${ }^{10,11}$. Annukka Vainio ${ }^{10,12} \cdot$ Reetta Toivanen $^{10,19} \cdot$ Timon McPhearson $^{13,17,18}$. \\ Michiru Nagatsu 8,10
}

Received: 19 February 2021 / Accepted: 11 November 2021 / Published online: 1 December 2021

(c) The Author(s) 2021

\begin{abstract}
Sustainability transformations call forth new forms and systems of knowledge across society. However, few tools and processes exist for promoting dialogue among different interests and normative stances in knowledge co-creation. In this article, we build on the notion of thought collectives to argue that understanding and moderating normative tensions are necessary if sustainability science is to provide successful solutions. Drawing on an analysis of the normative tensions between rival high-tech and lowtech thought collectives in the mobility and food production sectors, we discuss three strategic approaches: applying common evaluative frameworks, building contextual convergence and embracing complexity. We argue that these strategies indicate a need to distinguish different kinds of reflexivity in managing tensions among thought collectives. As a practical conclusion, we establish sets of reflexive questions to help sustainability scientists deploy the knowledge management strategies discussed.
\end{abstract}

Handled by Osamu Saito, Institute for Global Environmental strategies, Japan.

Niko Soininen

niko.soininen@uef.fi

1 Center for Climate Change, Energy and Environmental Law, Department of Law, University of Eastern Finland, Joensuu, Finland

2 Ecosystems and Environment Research Program, Faculty of Biological and Environmental Sciences, Helsinki Institute of Sustainability Science (HELSUS), University of Helsinki, Helsinki, Finland

3 Department of Economics and Management, Faculty of Agriculture and Forestry, Helsinki Institute of Sustainability Science (HELSUS), University of Helsinki, Helsinki, Finland

4 Department of Agricultural Sciences, Faculty of Agriculture and Forestry, Helsinki Institute of Sustainability Science (HELSUS), University of Helsinki, Helsinki, Finland

5 Department of Computer Science and Helsinki Institute of Sustainability Science (HELSUS), University of Helsinki, Helsinki, Finland

6 Department of Philosophy, Lund University, Lund, Sweden

7 Hungarian Department of Biology and Ecology, Babes-Bolyai University, Cluj-Napoca, Romania

8 Practical Philosophy, Faculty of Social Sciences and Helsinki Institute of Sustainability Science (HELSUS), University of Helsinki, Helsinki, Finland
9 Aalto University, School of Arts, Design and Architecture, Helsinki, Finland

10 Helsinki Institute of Sustainability Science (HELSUS), University of Helsinki, Helsinki, Finland

11 Faculty of Arts, Helsinki Institute of Sustainability Science (HELSUS), University of Helsinki, Helsinki, Finland

12 Department of Forest Sciences, Helsinki Institute of Sustainability Science (HELSUS), University of Helsinki, Helsinki, Finland

13 The New School, Urban Systems Lab, New York City, NY, USA

14 UEF//Water, University of Eastern Finland, Kuopio, Finland

15 Department of Landscape Architecture, Planning and Management, Swedish University of Agricultural Sciences, Uppsala, Sweden

16 Natural Resources Institute Finland, Helsinki, Finland

17 Cary Institute of Ecosystem Studies, New York City, NY, USA

18 Stockholm Resilience Centre, Stockholm University, Stockholm, Sweden

19 Faculty of Arts, Department of Cultures, University of Helsinki, Helsinki, Finland 
Keywords Thought collective $\cdot$ Sustainability science . Research management $\cdot$ Reflexivity $\cdot$ Mobility $\cdot$ Food production

\section{Introduction}

Systemic and rapid shifts towards sustainability across diverse sectors of society require new forms and systems of knowledge that span structures, practices, cultures and values (Fazey et al. 2020). Developments in sustainability science increasingly emphasise new collaborative practices, such as participatory action, citizen science as well as co-creative and transformational research (e.g., Bonney et al. 2014; Norström et al. 2020). At local scales, we see the benefits of such collaboration. For example, active urban experimentations, including City Labs, provide milieus for knowledge co-creation and testing of new sustainability solutions (e.g., Frantzeskaki and Kabisch 2016; Frantzeskaki et al. 2018). However, visions of desirable transformations and how to achieve them diverge considerably among different social groups, making it difficult to scale sustainability solutions. For example, groups emphasising technology-led transformation can differ in their views from those espousing market-, state- or citizen-led transformation (Scoones 2016) or those advocating nature-based solutions (Turnhout et al. 2020). Such systemic challenges are generally addressed by bridge-building between natural and social sciences (interdisciplinarity) or between academia and society (transdisciplinarity) (Kuhn 1962; Funtowicz and Ravetz 1993; Brewer 1999; Klein 2010; Wiek et al. 2012; Lang et al. 2012; Bernstein 2015; Osborne 2015).

Yet, discussions of inter- and transdisciplinarity often miss the point that values and practical orientations do not neatly coincide with any existing disciplinary or sectoral divisions. More recent action-oriented and co-productive approaches in sustainability science (e.g., Caniglia et al. 2021; Fazey et al. 2020) emphasise a balance between pluralism and integration of different kinds of knowledge or ways of knowing, including traditional ecological knowledges; however, they do not offer strategies for managing diverging visions of sustainability (Turnhout et al. 2020). To directly address the challenge of bridging divergent perspectives, we deploy the concept of a thought collective (Fleck 1979 [1935]), defined as a group of individuals bound together by shared epistemic and nonepistemic claims about truth (see Sect. 2 for further details).

On a coarse scale, sustainability science can be characterised as a thought collective that typically takes a systems perspective on sustainability challenges to discern patterns and articulate scientifically sound and societally viable solutions (Kläy et al. 2015). However, on a finer scale, differing thought collectives emerge - ones that favour certain sustainability solutions over others and often represent different views on the benefits and costs of such solutions. Taking examples from the food sector, at one end of the spectrum we may find high-tech thought collectives that rely heavily on new technologies and leapfrogging development (e.g., cellular agriculture and genetically modified organisms (GMO); at the other end, we may find low-tech collectives resorting to less technology-driven and more traditional approaches to sustainability (e.g., traditional farming practices) (see Sect. 2). Collectives at both ends of the spectrum are committed to sustainability as an overarching normative goal but view the costs and benefits of their preferred sustainability solutions, and the pathways towards them, differently. This raises important questions: Where does this plurality originate? Is it a problem for sustainability? If so, what strategies can be deployed to deal with it? Finally, what kind of practices are needed to make sense of the normative tensions between thought collectives and their preferred sustainability solutions?

The formation of thought collectives has arguably increased fruitful interaction between scientific disciplines on the one hand, and between science and society on the other, as such collectives question the taken-for-granted assumptions within disciplines. However, the management of normative tensions between thought collectives has attracted rather less scholarly attention. Researchers typically aim to identify the philosophical, structural and conceptual differences between collectives (e.g., Cahill and Humphrys 2019), and in some cases ask why the differences exist and what purposes they serve (Pohl and Wuelser 2019). However, to date few tools and processes have emerged for promoting dialogue and more discerning discussion across thought collectives having very different normative stances on sustainability solutions (Lahsen and Turnhout 2021). While different views are important for academic debate and scientific progress, in many cases views become entrenched, forcing decision-makers to choose sides when it comes to appropriate future directions for central sustainability challenges. Further polarisation of communities also risks unravelling the social capital (networks and trust) underpinning solutions-oriented sustainability science in the future. We argue that sustainability science's success in providing solutions for society depends on its capacity to understand and moderate normative tensions among thought collectives and to take seriously different embedded worldviews, values and methods. We propose methodological strategies for managing tensions across thought collectives in sustainability science and discuss how different strategies are underpinned by distinct types of reflexivity. Our analysis makes clear what we should be reflexive about as well as why and how we should be reflexive, responding to the recent calls for moving beyond engaging merely in 'more reflexivity' (Böstrom et al. 2017; Montana et al. 2020) in the environmental sciences.

We build our argument around examples of two rivalalbeit simplified-thought collectives with preferred solutions for tackling sustainability challenges in each of two sectors, mobility and food production. The rival collectives 
in each case can be characterised as 'high-tech' and 'lowtech'. Being high-tech means loosely leapfrogging development to sustainability by technological means (e.g., autonomous vehicles in mobility and cellular agriculture and GMOs in food production), whereas low-tech means improving planning and management to realise this goal (e.g., integrated and densified urban planning in mobility and traditional farming practices, such as organic farming, in food production) (cf. Alexander and Yacoumis 2018). It should be noted already at this point that the designations high-tech and low-tech are points on a continuum, rather than categories in a strict dichotomy. Moreover, to make the normative assumptions behind different thought collectives clear, we present a somewhat sharper distinction between the collectives than can be empirically observed.

Section 2 begins by introducing and motivating our choice of a thought collective as an analytical unit. It then goes on to describe the sustainability challenge, the highand low-tech thought collectives emerging to tackle it and the collectives' respective strengths and weaknesses in the mobility and food sectors (2.1-2.2). In Sect. 3, we systematise three knowledge-system management strategies for making sense of and moderating the value-laden debates about sustainability (3.1-3.3). We continue in Sect. 4 by discussing the type of reflexivity the adoption of each strategy requires (4.1-4.3) and conclude by discussing a way forward for achieving more reflexive sustainability science.

\section{Thought collectives, sustainability solutions and normative tensions}

The concept of a thought collective (Fleck 1979 [1935]) refers to a group of individuals who share the practice of exchanging and developing of ideas. The members of a thought collective come to share a thought style - a way of thinking and reasoning grounded in some set of epistemic and non-epistemic values - that serves to set the collective's priorities as regards the kinds of problems that are important and how these can and should be solved. A thought collective is formed through close interactions and shared experiences of practitioners and scientists, but once formed it acts on its members to constrain and direct their values and cognition (see Hacking 2002 on styles of reasoning).

In addition to allowing analysis of collectives that cut across disciplines and sectors, Fleck's framework has at least two other benefits. First, it is analytically and descriptively useful in highlighting that the rival perspectives we contrast in Sect. 2 are not mere bundles of solutions; rather, they are positions of groups of people who hold particular (implicit and explicit) normative stances on how problems should be framed and structured and how different technologies can and should be applied and mainstreamed/scaled. Kuhn's better-known notion of a paradigm, though acknowledging the collective and social nature of cognition to some extent, focuses more on theoretical commitments as the glue of a collective. The concept is less relevant to solution-oriented sustainability science than to his original episodes in mature sciences such as physics and chemistry. Second, Fleck's approach is also practically useful, because its focus on practices and experiences as the grounding of thought collectives implies the possibility of negotiating values and practices across collectives. The envisioned integration does not require theoretical unification or a paradigm shift, but instead suggests practice-focused knowledge-management strategies such as those we outline in Sect. 3. ${ }^{1}$

Multiple thought collectives with different views on sustainability challenges and ways of overcoming them have been discussed in the sustainability science literature. One can cite those collectives drawing on the intrinsic values of nature as an ethical basis for conserving natural entities in contrast to those emphasising an instrumental approach (Justus et al. 2009; Mace 2014; Taylor et al. 2020) or a more pluralistic approach (Zafra-Calvo et al. 2020; Pascual et al. 2021). Other collectives again emphasise the practical stream of social innovation in sustainable energy transitions, in which new social innovation projects complement more traditional technological and efficiency-driven innovation. Contrasting with these are the collectives in the critical stream which maintain that social innovation is not simply an add-on to technological innovation (Wittmayer et al. 2020). In what follows, we draw upon examples of thought collectives in the mobility and food sectors, these being areas in which we have expertise. Our analysis serves to shine a spotlight on the normative tensions associated with the management of tangible sustainability challenges.

\section{Rival thought collectives in urban mobility: autonomous vehicles vs. integrated and densified spatial planning}

Transport is an important area in the context of sustainability transformations because of its environmental, social and economic impacts. At present, 1.35 million people are killed and 10 million injured in car accidents every year globally (World Health Organization 2018). Traffic is the leading cause of death among 5- to 29-year-olds. According to the latest report of the Intergovernmental Panel on Climate Change (IPCC), transportation also accounts for

\footnotetext{
1 Another prominent analytical category in science and technology studies is the sociotechnical imaginary, a collective vision and policy framework for achieving a good future through technology development (Jasanoff and Kim 2015; Longhurst and Chilvers 2019). Different thought collectives may share the same imaginary in this sense, and yet diverge on how best to realise the vision because of their distinct thought styles. Focusing on thought collectives is thus a useful heuristic in developing strategies for managing such divergence.
} 
23 per cent of total energy-related $\mathrm{CO} 2$ emissions globally (7.0 GtCO2eq, IPCC 2018). In this light, it is not surprising that the Sustainable Development Goals (SDG) for road safety aim at halving the number of global deaths and injuries (SDG 3) and providing safe, affordable, accessible and sustainable transport systems for all (SDG 11).

Thought collectives that have emerged to provide solutions to these sustainability challenges of urban mobility diverge in composition and in their solutions along the high-tech-lowtech continuum (Timms et al. 2014). On the high-tech side, the thought collective developing cars (e.g., car-shaped autonomous vehicles) is building upon automobility rationalities and car cultures. Car cultures and consumption entail more than rational choices; they embody social patterns with aesthetic and affective elements (Sheller 2004). There are even rival thought collectives within the high-tech collective, which comprises governmental and city planning representatives who envisage a future with shared autonomous vehicles and autonomous public transport (Fraedrich et al. 2019).

The high-tech collectives

At the high-tech end of the spectrum are collectives that rely on the emergence of a completely autonomous traffic ecosystem consisting of autonomous public transportation, autonomous private cars and unmanned aerial vehicles (UAVs) that will make it possible to achieve the sustainability goals set for mobility. The rationale of high-tech collectives builds on safety, emission reduction and efficiency gains in using shared private vehicles (Milakis et al. 2017). The collectives consist mostly of artificial intelligence (AI) and transportation specialists in academia and in industry According to the high-tech collectives, autonomous vehicles provide a smoother driving experience compared to human-operated cars, as they are connected to an intelligent traffic ecosystem where vehicles can adjust their speed to traffic lights, drive closer to each other and drive faster due to advanced communications between vehicles. Autonomous vehicles also have fewer accidents, as the majority of accidents globally (93\%) are caused by human error (Singh 2015). As the frequency of accidents is reduced, vehicles can be made much lighter, improving fuel economy and reducing range issues that limit the use of electricity and other alternative fuels (Anderson et al. 2016). Autonomous vehicles can also improve work efficiency as commutes may be used for working in the vehicle. Autonomous driving could improve social equality by enabling independence and reduced social isolation for the blind, disabled and others who are not able to drive or easily use public transportation (Anderson et al. 2016). A dystopian version of high-tech solutions includes many more vehicles on the roads. If transport systems are more efficient in managing the available space for mobility, current road networks can carry a much higher number of cars than they do today. Total carbon emissions may end up increasing instead of declining (Wadud et al. 2016). Moreover, without taking careful regulatory actions in implementing the autonomous traffic ecosystem, autonomous vehicles would be used for continuing the dominance of individual personal cars and not for improving means of public transportation, resulting in inequality in mobility (Mladenovic and McPherson 2016; Sparrow and Howard 2020). Autonomous vehicles may also require costly, additional investments, such as significant $5 \mathrm{G}$ network coverage and capacity

\section{The low-tech collectives}

At the low-tech end of the spectrum are thought collectives that rely mainly on re-prioritising the already existing transportation technologies and increasing their efficiency and connectedness. The low-tech collectives consist mainly of urban planning, transportation and mobility scholars and professionals, as well as urban activist groups. These collectives typically argue that more fundamental changes in urban design and planning are needed to reach SDGs 3 and 11 (Banister 2011; Sustar et al. 2020). The low-tech view emphasises an overall shift in paradigm from private-vehicle-centred planning to human-centred planning (Gehl 2010) in order to create socially and ecologically more just transportation cultures (Martens 2016; Sheller 2018)

Besides prioritizing the development of public transportation networks, urban planning oriented low-tech collectives would tackle the sustainability challenges of mobility by integrating and densifying residential, commercial and leisure districts to decrease the need for mobility (Meurs and Haaijer 2001; Gallo and Marinelli 2020). Decreased number of vehicles on the road would contribute to sustainability also through a lower rate of accidents and decreased $\mathrm{CO}_{2}$ emissions (Hickman and Banister 2014; Mladenovic et al. 2020). The low-tech dystopia is that the change in existing transportation and planning paradigms would be too slow for reaching the sustainability goals. Implementation of the low-tech future requires remarkable change in the attitudes and behaviour of people on the move. Even though owning a private car is a lifestyle choice to some degree (Zhang 2017), the low-tech solutions aim at challenging this identity-related perception of the private vehicle by more accessible and integrated forms of public transportation network and by making alternative transport modes such as bicycling and walking more lucrative choices. Moreover, these choices are constrained by the existing infrastructure and urban planning and may require unrealistic levels of regulation and government coercion to become a reality, especially outside densely populated urban areas

\section{Rival thought collectives in food production: cellular agriculture and GMOs vs. traditional farming practices}

Food systems are one of the main drivers of environmental change, yet their contribution to human health and wellbeing is crucial (Campbell et al. 2017; Tuomisto et al. 2017; Willet et al. 2019). The mounting evidence of the need for health- and environment-related changes in food production and nutrition practices (Popkin 2006; Johnston, Fanzo and Cogill 2014; Willett et al. 2019) has sparked calls to address the sustainability of the food system (Tilman and Clark 2014; Springmann et al. 2016; Clark et al. 2019; Willett et al. 2019). As the global population increases and income levels rise, food demand will increase in turn, in particular demand for animal-derived foods (Myers et al. 2017). Increased demand for crops could require one billion additional hectares of land to be cleared and result in greenhouse gas (GHG) equivalent emissions exceeding three gigatons per year if land continues to be cleared in poor nations for agricultural expansion by rich nations (Tilman et al. 2011). 
Food is directly or indirectly linked to all SDGs, most closely to those conceived to reduce malnutrition (SDG 2), improve health and well-being (SDG 3), promote responsible consumption and production (SDG 12), combat climate change (SDG 13), conserve marine resources (SDG 14) and promote the sustainable use of terrestrial ecosystems (SDG 15). It is widely agreed that the transformation of food systems to achieve the SDGs requires efforts on the part of all actors in the food systems at different levels, with these including major changes in policies, technologies and practices (FAO 2018).

Thought collectives have disagreements regarding the means to achieve the shared goals. Previous studies have shown that in the context of agri-food technologies the main considerations have been (un)naturalness, trust in natural sciences, risk management, ethics, the uncertainty of longterm effects, and wider societal impacts (Marcu et al. (2015). Low-tech collectives propose reducing agricultural crop demand through sustainable dietary practices and changing the way food is produced through various sustainable food production practices (e.g., Agroecological Symbiosis) that could reduce land clearing, water use and associated species extinctions (Tilman and Clark 2014; Koppelmäki et al. 2019).

In contrast, novel, high-tech food production technologies (e.g., cultured meat, microbial proteins, cultured plant cells) may provide food for future diets while meeting multiple sustainability goals, such as lower environmental impacts, meeting essential nutritional needs for broader populations and providing viable alternatives to current animal-based foods (Tuomisto 2019). When compared to current animalsource foods, these novel, high-tech foods can have significant environmental benefits and ensure the nutritional adequacy of diets (Parodi et al. 2018). Foods produced through cellular agriculture can have a complete array of essential nutrients (e.g., protein, calcium, B12, Omega-3) and are more water- and land-efficient, making them viable alternatives to animal-source foods (Parodi et al. 2018). The two rival thought collectives in food systems have been theorised as possible post-Anthropocene futures for sustainable food systems (Mazac and Tuomisto 2020).

\section{Diagnosing the tensions}

Spelling out the differences between the two thought collectives in urban mobility and in food production, respectively, offers an interesting perspective on broader questions of sustainability science: when we see thought collectives diverging on sustainability solutions, what are we seeing? In this section we identify four different sources of normative disconnect between the thought collectives: 1. risk and uncertainty; 2. efficiency; 3 . agency and power. and 4. ethics and justice. Each tension is described in a separate paragraph and the four are summarised in Table 1.

\section{Mobility sector}

In the case of risks and uncertainties in the urban mobility sector, representatives of the high-tech thought collectives usually have knowledge of and familiarity with the technologies related to autonomous vehicles (Penmetsa et al. 2019). However, they generally do not have enough knowledge of the changing societal conditions. The knowledge of lowtech thought collectives is often based on the current transportation system and its deficiencies rather than emerging future technologies (Mladenović 2019). Due to their differing worldviews, thought collectives supportive of "smart" and "sustainable" solutions view risk and uncertainties differently when compared with low-tech collectives (Lyons 2018).

Regarding efficiency, the high-tech thought collectives think that autonomous vehicles will bring benefits, as humans can use their time more effectively by working while in the vehicles (Fagnant and Kockelman 2014). However, one of the concerns of the low-tech thought collectives here is that this belief overlooks the effect of motion sickness and considers only white-collar labour (Fagnant and Kockelman 2015). The rival thought collectives address efficiency, energy efficiency in particular, in a very different way.

In the case of agency and power, the high-tech thought collectives worry that, despite regulation, the reduction in automobility will not be enough to provide significant sustainability benefits (Ewing et al. 2017). According to the low-tech collectives, the high-tech collectives underestimate the importance of human agency in driving sustainability transitions (Spaargaren et al. 2011). Both thought collectives think that their pathways will bring social justice when driving and owning a car are no longer required (Sheller 2018). The former collectives see a way forward in using shared autonomous vehicles, the latter in decreasing the need to travel and investing in lighter modes of transport, such as cycling and walking.

As regards ethics and justice, the low-tech thought collectives are worried about questions of future responsibility if the pathway favouring autonomous driving is realised (Koopman and Wagner 2017; Burton et al. 2020). Who will be responsible if there is an accident? Will it be the entity who developed the software, the one who developed the hardware (sensors) or the one who assembled the vehicle and sold it (Collingwood 2017)? How should the law and ethics address decision-making in a situation where the vehicle must choose whose life to save (Awad et al. 2018)? Who will own and store our data (Gulsrud et al. 2018)? The low-tech collectives are also concerned that citizens may have unequal possibilities to use autonomous vehicles and 


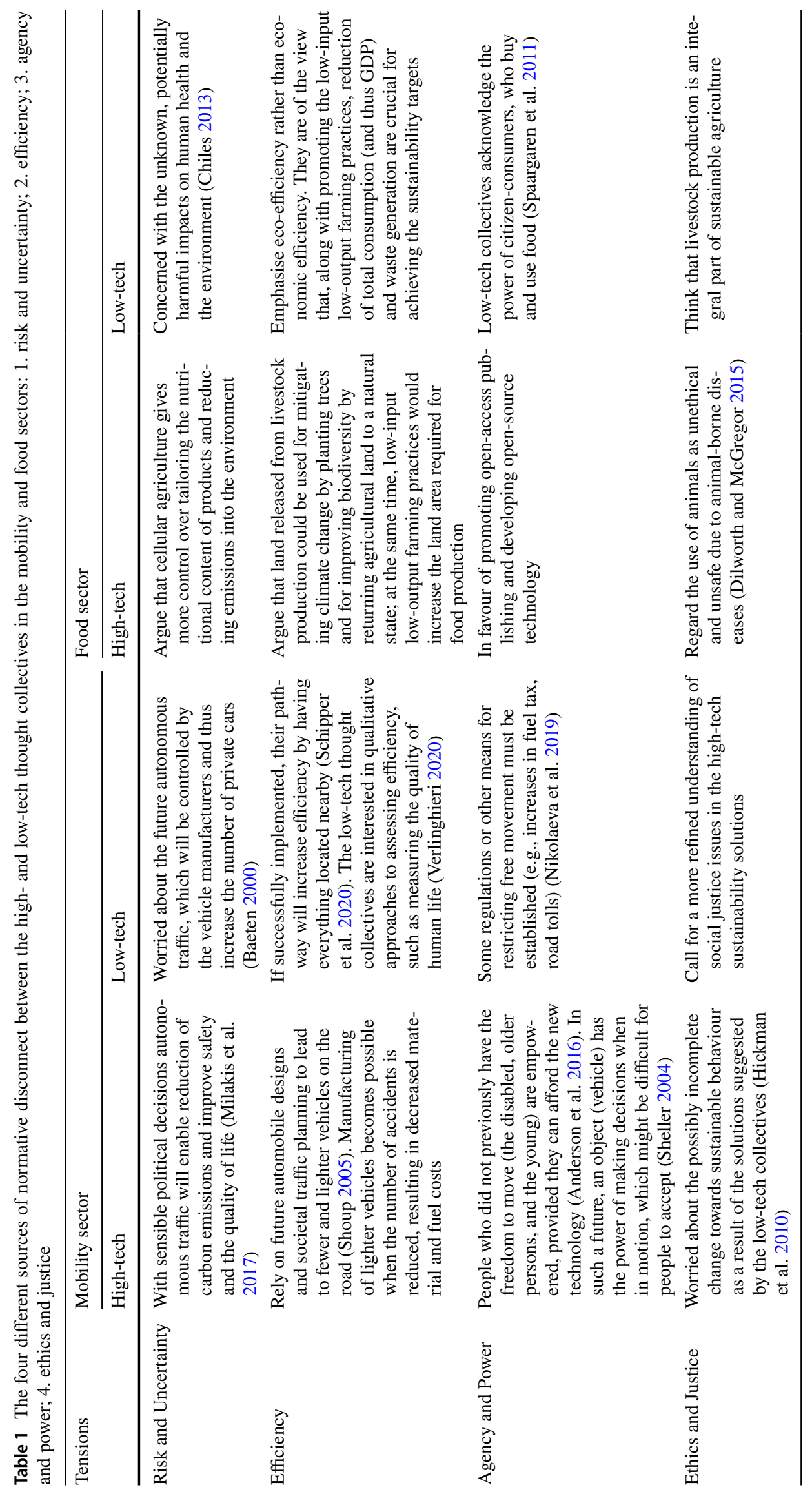


that the attractiveness of autonomous vehicles might reduce walking or biking. This would reduce well-being and might ultimately lead to an increase rather than a decrease in the use of vehicles. Perhaps the key question to be addressed is, will it be possible to establish regulation to change people's mobility behaviour to minimise car use and will this negatively impact their scope of mobility (Anable 2005; Bothos et al. 2014; Anagnostopoulou et al. 2020)?

\section{Food sector}

Regarding risk and uncertainty, the high-tech thought collectives consider the risks of not using the novel technologies higher than the potential unknown risks, whereas the lowtech collectives espouse the opposite view.

In the case of efficiency, the low-tech thought collectives argue that the high-tech collectives' focus on improving the efficiency of food production per unit of product will not lead to improved sustainability at the food system level, as greater efficiency may result in greater consumption (Böhm et al. 2018). For instance, a shift from outdoor agriculture to cellular agriculture could reduce the land area required for food production but might increase biofuel and bio-based material production on the fields, leading to even more serious sustainability challenges than at present.

The views on the importance of distribution of power also differ between the thought collectives. The low-tech thought collectives regard the concentration of power in only a few actors as problematic and would prefer to disperse power across small producers (Miller 2012). As the lowtech farming practices are not patented, the access barrier to food production is low, requiring only simple resources and local knowledge about farming. Even though the high-tech thought collectives may share the concerns regarding the concentration of power, they do not think that the associated risks are so high that they will prevent the development of the technologies.

Where ethics and justice in the food system are concerned, low-tech thought collectives think that livestock production is an integral part of sustainable agriculture, whereas the high-tech collectives regard the use of animals as unethical and unsafe due to animal-borne diseases (Dilworth and McGregor 2015).

All in all, our analysis above suggests that a fundamental plurality of values relating to (1) risk and uncertainty, (2) efficiency, (3) agency and power and (4) ethics and justice underlies the visions for sustainability transformation. Moreover, we would argue that the causal complexity and multiscale nature (both temporal and spatial) of the problems defy any attempt to evaluate these values within a single category, let alone a combination of categories. This analysis points to a need for meta-discussions on strategies for managing such value plurality (Norton 2017), to which we turn next in Sect. 3.

\section{Knowledge-system strategies for managing diverging sustainability solutions}

In this section, we present three different approaches that couple procedural and methodological elements in order to manage the normative tensions between high- and low-tech thought collectives such as those identified the previous section: (1) developing a common evaluative framework for identifying co-benefits and trade-offs between different positions, (2) shifting attention to the pragmatic decision-making processes protecting and encouraging the multiple values expressed by different thought collectives within a given situation and (3) allowing complexity and tensions to persist by avoiding common evaluation and contextual convergence.

Multiple approaches exist for dealing with normative tensions and conflicts in sustainability challenges, with these including individualistic approaches for building empathic and emotional engagement (Brown et al. 2019); collaborative approaches, whose aim is to coordinate different interests and reach solutions (Majer et al. 2021); and emergent, transdisciplinary design research, in which the research process is designed as it unfolds to cater for high levels of complexity, conflict and social fluidity (Breda and Swilling 2019).

Here, building on Stepanova et al. (2020), we focus on the different rationalities which underpin normative/target knowledge concerning appropriate goals for action. Current sustainability science literature can be systematised in the form of a gradient of three broad strategies with different modes for managing normative tensions between thought collectives. First, the common evaluative framework emphasises logic, argumentation, and the use of different forms of statistical aggregation to identify and optimise sustainability solutions based on differing perspectives. The emphasis is on statistical rather than political argumentation. Second, the pragmatic decision-making process recognises the importance of situating the collectives' differing values and interests in a specific problem context, and emphasises different forms of deliberation and negotiation to support, where possible, the achievement of shared values. Third, exploring complexity does not seek to support consensus but rather to bring conflicts to the surface in order to reveal new or alternative ways of dealing with sustainability challenges. (Fig. 1).

While these three approaches may not cover all existing knowledge-system management strategies, our view is that they cover the main lines of engagement in sustainability science literature. Each strategy is discussed in detail below. 


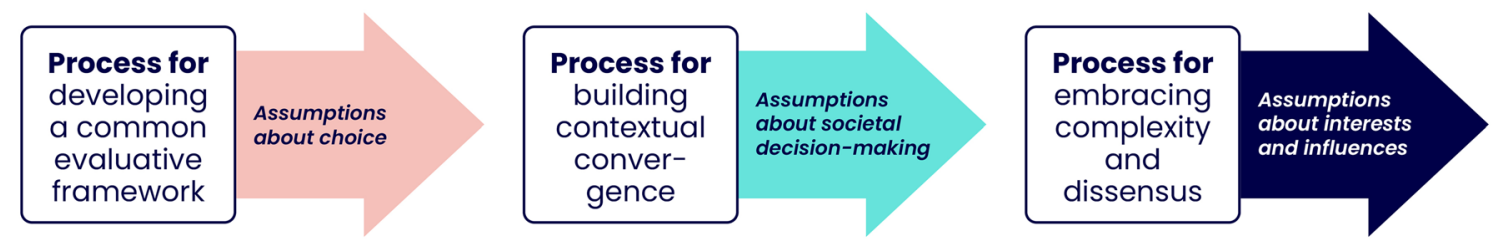

Fig. 1 Three strategies forming a gradient for managing tensions between thought collectives and their respective assumptions

\section{Developing a common evaluative framework: in search of a supervalue and shared metrics}

The first knowledge-system strategy for managing tensions between different thought collectives is to set up a process that seeks to establish a common evaluative framework for comparing the co-benefits and trade-offs between sustainability solutions. One key normative driver behind such a strategy is convergence-building between the different evaluation methods and values underpinning sustainability solutions. Common evaluative frameworks operate under the assumption that different evaluation methods, values and sustainability solutions are commensurate and can be reduced to shared supervalues (e.g., Pareto efficiency) and metrics (e.g., the World Bank's Adjusted Net Savings, ANS); if not commensurable, the methods at least have comparable units and methods (Kronenberg and Andersson 2019). If such a supervalue and the accompanying metrics can be agreed upon, common evaluative frameworks are useful in establishing a basis for assessing competing sustainability solutions (see Wallace et al. 2021). Some integrated assessment models (IAMs) in climate policy (e.g., the Dynamic Integrated Climate Change (DICE) model) represent such frameworks (Nordhaus and Boyer 2000). Where commensurate metrics are lacking, other consistent frameworks are used, such as Multi-Criteria Decision Analysis (MCDA), which allows one to compare alternatives against a set of explicitly defined criteria (Langemeyer et al. 2016, 2020; Kremer et al. 2016). The criteria are assessed, weighted and aggregated in the analysis phase and then ranked by stakeholders in the decision phase to inform different land-use options, for example (Esmail and Geneletti 2018). Other common frameworks include Bayesian Belief Networks (Barton et al. 2016) and the Vector Analytic Hierarchy Process (Arnette et al. 2010).

The main benefit of the common evaluative framework approach is that it provides a systematic and mutually agreeable basis for evaluating alternative futures. If the building of a shared evaluative framework succeeds, it can provide decision-makers a significant resource to evaluate synergies and trade-offs. On the downside, reducing the different sustainability solutions to a common evaluative framework risks foregrounding certain values and metrics, such as quantifiable costs and benefits, and downplaying other values that may not be amenable to aggregation, examples being a diversity of relational values grounded in the ethics of reciprocity and care (Chan et al. 2016; Himes and Muraca 2018) and traditional ecological knowledge (Casi et al. 2021). Proponents of some knowledge systems resist having their values reduced to preference rankings, because such rankings discount interactions and feedback processes deemed crucial to their culture and way of life (e.g., Raymond et al. 2013; O'Connor and Kenter 2019). Furthermore, this instrumental logic does not allow hierarchies between scientific and other knowledge holders to be challenged (Turnhout et al. 2020).

In the mobility sector, studies have sought to optimise multi-criteria functions, such as accessibility, safety, legal rules, passenger preferences (e.g., comfort) and energy consumption (Campos et al. 2009; Claussmann et al. 2018). For example, Multi-actor Multi-criteria Analysis (MAMCA) can include multiple stakeholders in the process of making decisions about sustainable mobility, including an assessment of low-carbon transport policy (Huang et al. 2021). Core to this approach is stakeholder analysis, the creation of assessment criteria, indicators and weights, and formulation of criteria for the analysis and ranking of weights (Macharis and Baudry 2018). In workshop environments, stakeholders have an opportunity to interactively weigh and evaluate scenarios in a tool. While different thought collectives may rank alternatives differently based on their own values, the MAMCA model is able to limit the set of good options to one or two alternatives in light of the optimal solution (Huang et al. 2021).

In the food sector, the Life Cycle Assessment (LCA) method is commonly used for estimating the environmental efficiency of agriculture and food production (Poore and Nemecek 2018). Proponents of low-tech farming practices have criticised the method, as it favours high-yield farming systems that use resources efficiently but ignores ecosystem services that low-yield farming systems provide (van der Werf et al. 2020). This criticism has led to the development of methods that combine traditional LCA with more advanced ecosystem service assessment (e.g., Jeswani et al. 2018). The LCA method is also criticised for the bias caused by subjective choices during the analysis. In other words, the LCA practitioner can either knowingly or unknowingly influence the results of the analysis through the 
methodological choices and assumptions he or she makes. Proponents of LCA have sought to address this weakness through increased use of multi-criteria decision analysis and participatory methods in combination with LCA (De Luca 2017).

Although common evaluative frameworks are valuable tools for understanding complex phenomena and aid decision-making, their operation assumes commensurable or comparable metrics. Given that different values underlying different thought collectives are not always commensurable (in optimisation) or comparable (in multi-criteria), as is the case in our mobility and food examples, what other alternatives are there to manage normative tensions?

\section{Building contextual convergence: plural inputs to practical decision-making}

The second knowledge-system management strategy embarks from a different starting point than common evaluative frameworks do. The process for building convergence recognises that different value domains exist and cannot be aggregated or reduced to some supervalue or shared metric (Chang 2001; O'Neill et al. 2008; Mason 2015; AriasArevalo et al. 2018). In this situational or plural valuation approach, it is assumed that no single, overarching system of evaluation can identify a single, optimal outcome. This strategy thus shifts the procedural emphasis from "what has value and how much" (i.e., the common evaluative framework approach) to the development of processes which enable diverse values to surface and be negotiated when considering tangible real-world problems in particular situations (Norton 2015, 2017; Zafra-Calvo et al. 2020).

The benefit of the strategy is that it seeks to connect knowledge to action-oriented approaches and to break down power, gender, economic and social inequalities among thought collectives. It also seeks to break down systems, structures, practices and highly specialised communications-akin to those found in a thought collective. This approach also allows for sustained feedback among negotiation, decisions, actions and outcomes, enabling different thought collectives to understand each other's perspectives and potentially reach a compromise.

One of the weaknesses of the strategy approach is that it is highly dependent on strong collaboration and communication among stakeholders and requires an institutional capacity for long-term participatory processes involving dialogue and negotiation (Zafra-Calvo et al. 2020). Those applying the approach rely upon boundary organisations that have the capacity and normative desire to connect key actors across thought collectives. In some cases, knowledge co-creation processes can be compromised by power asymmetries, prompting a need for culturally sensitive dialogues (Matuk et al. 2020).
In the mobility sector, there is no specific academic literature focusing comprehensively on connecting future autonomous vehicle-based traffic and the urban planning perspective (Williams et al. 2020, cf. Thomopoulos and Givoni 2015; Mohorčich 2020). Williams et al. (2020) urge research communities and funders to start working actively towards such collaboration. However, examples can be found in the wider sustainable transport domain. Sustainable transport cases from Santiago and Temuco, Chile, have demonstrated the possibilities for deliberative valuation and collaboration between citizens and the School of Transport Engineering at the Pontificia Universidad Católica (Chile) and a citizens' urban planning organisation, Living City (Sagaris 2018). A living laboratory, grounded in participatory action research, was established to shift from a bureaucratic approach to sustainable transport to a collaborative approach seeking convergence in values, concerns and preferences across citizens and different sectors of transport planning. As part of the development of the Temuco-Padre Las Casas sustainable transport plan, a process of free dialogue between participants and planning actors was established to openly discuss differing values associated with road safety and quality of urban space, social inclusion, gender and multiple-mode transport. The project educated citizens and government on how to use a Goal Achievement Matrix to evaluate how well specific projects and programmes align with the values, concerns and preferences of citizens and the transport sector. Despite the plurality of values and concerns, convergence was built across differing perspectives, encouraging consistency in plan implementation. People with visual, physical and mental disabilities participated and identified issues of discrimination in the plan. The result was an innovative and more integrated plan with active engagement on the part of multiple stakeholders (Sagaris 2018).

In the food sector, the discussion on GMOs in the EU is an illustrative example of a procedural effort to support the convergence of thought collectives. To mitigate the tensions between different thought collectives, the European Food Safety Agency (EFSA 2005) has a permanent Stakeholder Consultative Platform to facilitate dialogue between consumer groups, food and feed business operators, the food industry, the food trade and food-related NGOs. The platform advises EFSA regarding its work programme and consultation practices, provides feedback on the effectiveness of its policies, alerts it to key issues of current or emerging concerns and risks and provides information and facilitates cooperation at the technical level (EFSA 2005). The meetings take place on average three times per year. In the context of the development of GMO policies, the platform is seen as a step towards a more inclusive approach and contribution to democratic legitimacy (Dabrowska 2007). The practice has 
also laid the ground for an interactive exchange of views between different thought collectives and enhanced mutual learning.

But what happens when such a procedural approach fails? How do we identify the meanings which are lost during the process, when inequalities become even more pronounced (e.g., Isaksson and Richardson 2009)? And what are the consequences of decisions based on this knowledge for culturally and ethically justifiable futures (Matuk et al. 2020; Turnhout et al. 2020)? Depoliticisation of power relations is common to knowledge co-creation in sustainability science, particularly when striving for a consensus that is considered appropriate from a given thought collective's perspective, or when failing to consider the wider political context in which sustainability solutions are embedded (Turnhout et al. 2020). The challenge is to move from a "position of powerover"-where some participants are dominated or manipulated by others-to "power-with" where all stakeholders are empowered (Turnhout et al. 2020). Conflicts and dissensus are unavoidable in situations where knowledge integration has substantial implications for power relations, necessitating new ways of embracing complexity, redundancy and disagreement (Krieg and Toivanen 2021). This is where it may be useful to establish a complexity-embracing process that makes no assumptions of convergence.

\section{Embracing complexity and dissensus-no assumption of convergence}

By definition, in a complex knowledge-system management strategy, sustainability scientists should not seek to establish common evaluative frameworks, or even establish a process seeking to build contextual convergence in specific decision-making situations through deliberation, negotiation and compromise. Rather, different actors should be brought together with the aim of hearing them out and arguing about their differing values, interests and concerns. The aim here would be to understand how each perspective contributes to grasping the complexity of the social, ecological and technological system and to understand the value of multiple competing claims to sustainability (Miller et al. 2011). The complexity-informed approach is based on complexity theory (Mitchell 2009; Capra and Luisi 2014). A similar epistemological stance in the philosophy of science, namely scientific pluralism (Chang 2012), supports this attitude without presupposing integration (cf. Mitchell 2002; Caniglia et al. 2021).

Procedures embracing complexity offer a valuable perspective for understanding the value of redundant, even competing and conflicting, sustainability solutions in helping to "avoid erroneous 'one-track', 'race to the future' visions of progress" (Stirling 2010, p. 1031). Moreover, the complexity strategy contributes to the repoliticisation of knowledge co-creation processes, reaffirming that conflict is an essential component of democracy (Turnhout et al. 2020). It thus offers a counterweight to contextual convergence (3.2), where there is often a tendency to reduce complexity to a 'shared' set of aspirational principles for designing, implementing, evaluating and scaling a given sustainability solution (Schäpke et al. 2018; Frantzeskaki et al. 2019).

On the downside, complexity-informed strategies offer no or very little help for decision-makers struggling to find the most effective, quick, or feasible pathways to sustainability. The strategy also suggest there is a high societal cost in both knowledge generation (multiple sustainability solutions developed in tandem) and the implementation of pathways (lack of integration). This cost risks draining public resources and slowing down transitions to sustainability before humanity crosses key global tipping points (Washbourne et al. 2020). Moreover, by relying on the emergence of new pathways from complex patterns, the strategies may render the conflict between thought collectives susceptible to hijacking by interests not willing to respect planetary boundaries (Smyth et al. 2017).

The mobility sector reflects complex dynamics of multiple forms of (human and non-human) agency and power at play (Kitchin et al. 2017). While conflicts between hightech and low-tech thought collectives often centre around mobility, accessibility, parking space, and the density of urban living (Shoup 2005; Anderson et al. 2016; Creutzig et al. 2016), there are many other forms of agency and decision-making that remain hidden to citizens. For example, complex algorithms used in various phases of autonomous vehicle operations enable new, complex forms of governance that are difficult to trace or access unless one has comprehensive knowledge of what is taking place (Bissell 2018). Complexity-informed processes will be important in politicising and making visible the different ethical standpoints and underlying logics of autonomous vehicles, enabling the public to better understand and balance the efficiency benefits of the new technologies in relation to critical social and personal health considerations.

In the food sector, despite widespread support for broad goals such as food security and sustainable food production and consumption, there may be disagreement between thought collectives on the actions required to achieve these goals (Tuomisto 2019). For example, there is a "repertoire of interpretations" of food security (Mooney and Hunt 2009; Carney 2012), each supported by its own thought collective and each having its own policy implications. Mooney and Hunt (2009) point out that there are three collective action frames underpinning the goal of food security (hunger, community and risk). The effort to achieve consensus inevitably generates contested claims that have substantive and normative dimensions. Unlike the plural perspective on values (3.2), this process leads to a contentious, multi-organisation 
political field of varying degrees of power wielded by different thought collectives, some being insiders to the science process, others outsiders (Mooney and Hunt 2009). Yet, current multi-stakeholder processes (MSPs) are criticised for their inability to make visible alternative ways of understanding the complex system and counter-hegemonic positions (Duncan and Claeys 2018).

Strategies 3.1-3.3 open a range of options for managing normative tensions between thought collectives. Although forming a range of options to how normative tensions can be managed, all three strategies embark from very different worldviews, strengths and weaknesses. One size does not fit all. The next section puts forward a set of reflexive questions that would help a sustainability scientist to evaluate which strategy fits a particular context and what kind of reflexivity is required in applying each strategy. The discussion on reflexivity concludes with the identification of key research gaps and new insights needed to realise the dormant potentialities of each knowledge-system management strategy.

\section{Practicing reflexivity at multiple levels: what should we be reflexive about?}

This section deals with how thought collectives can improve the application of the three knowledge-system management strategies through more reflexive practice. Our use of the notion of reflexivity is motivated by an increasing body of literature calling for reflexivity on the part of sustainability researchers (Wittmayer and Schapke 2014; Popa et al. 2015; Haider et al. 2018; Fam et al. 2020; Montana et al. 2020). This literature characterises reflexivity loosely as the critical awareness of one's taken-forgranted assumptions and values that guide one's research, as well as the ability to revise these through collaborative research in particular (see Suddaby et al. 2016 and Boström et al. 2016 for discussions grounded in sociology, from which the notion originates). The focus of the analyses is often on who should be reflexive-individual researchers, research groups or scientific fields as institutions-and how to implement reflexivity (von Wehrden et al. 2019; Freeth and Vilsmaier 2019; Montana et al. 2020). However, we consider it necessary first to explicate what we should be reflexive about more systematically (Suddaby et al. 2016). It is expected that divergence and convergence in thought collectives will be addressed by reflexivity on, for example, research stances in epistemology, methodology and implementation (Hazard et al. 2019) or reflexivity on implicit normative values that guide sustainability research (Wiek et al. 2011). Carrying out the knowledge-system management strategies identified in Sect. 3 will be different depending on the context of any given project. Distinguishing what we should be reflexive about during the application of the three strategies is a first step towards their deployment. Hence, we present a case for 'multi-level reflexivity' that will identify and apply each of the procedures sensibly.

\section{Assumptions in the model: reflexivity about methodological choices}

Practicing scientists often refer to the decisions about what assumptions to make in modelling as a matter of art and judgement, suggesting that such decisions draw on domain-specific and tacit expert knowledge (MuldoonSmith and McGuinness 2020), which is not transparent to outsiders. This mind-set is not exceptional in developing model-based common evaluative frameworks. Since these involve value-based parameter choices (e.g., what types of costs and benefits to consider; how much weight should be put on each; what the acceptable threshold of toxic chemicals in the environment is) as well as epistemic choices (e.g., how accurately to represent natural and social systems), the potential for divergence in opinions on how to choose the 'right' parameter looms even larger. Some scholars (e.g., Pindyck 2013, 2017) criticise Nordhaus's DICE model (Nordhaus 2017), a prominent IAM used in global climate policy, for example, for unjustified epistemic choices (e.g., the unrealistic damage function) while others (e.g., Winsberg 2018) criticise it for unjustified ethical assumptions of risk neutrality and the choice of a particular discount rate for future welfare.

The reflexive stance in the context of such contested integrated decision-support model-building means that scientists-individually or collectively-become more conscious and explicit about their epistemic and ethical choices. What is more, reflexive users also develop and adopt clear analytic guidelines to distinguish legitimate and illegitimate values (Intemann 2015), or to jointly analyse the ethical and evidentiary dimensions of modelbuilding for sustainability decision-making (Vezér et al. 2018; Valles et al. 2019). Researchers seeking to manage the role of values can, for example, ask reflexive questions such as the following to promote 'systemic accountability':

1. What are the strengths and weaknesses of the research practices in evidence gathering and analysis?

2. What are the research practices' ethical strengths and weaknesses?

3. How will the answer to Q1 affect ethical issues?

4. How will the answer to Q2 affect evidence gathering and analysis? (Valles et al. 2019, p. 270-271, slightly modified) 


\section{Assumptions about worldviews: reflexivity on societal decision-making context}

Disagreements on science-based sustainability policy are not limited to the choice of parameters and variables in integrated assessment models; rather they extend to the very choice of a given evaluative framework, especially when one tries to determine what the problem is in homogenising values among stakeholders. This type of disagreement over platforms reveals not only epistemic and ethical tensions (or their coupling), but also conflicting worldviews (e.g., about human nature or historical visions such as progress and enlightenment) and the metaphysics of values (e.g., anthropocentrism vs. non-anthropocentrism). For these reasons, we cannot expect any comprehensive evaluative framework to achieve universal support.

One way in which practitioners respond to this challenge is Participatory Modelling (PM) (Voinov and Bousquet 2010; Voinov et al. 2016, 2018), a type of iterative and interactive collaborative model-building process among scientists, stakeholders and decision-makers. In PM, non-scientists or non-modellers (whom we refer to as stakeholders here) play important roles in different degrees: some are subjects from whom information is extracted, some co-learning participants, and some even co-management partners (Lynam et al. 2007). Again, this process of stakeholder participation is often considered as "a craft, not a science" (Creighton 2005, cited in Voinov and Bousquet 2010, p. 1278), but in different ways than scientific modelling in general is an art form. First, researchers must consider what level of stakeholder involvement is appropriate, balancing their interests in and resources available for particular management and decision-making processes. Second, they have to assume the position of 'neutral' facilitators to gain stakeholders' trust in the process, while at the same time remaining explicit about their own partial interests (e.g., promotion of a favoured modelling approach or data collection for academic publications). Third, they must be responsible for the validation of models in two distinct senses (Voinov and Bousquet 2010). First, model components and assumptions have to be consistent and theoretically and empirically grounded (i.e., traditional objective validation). In addition, models have to be 'persuasive' and accepted among stakeholders as the right problem-frames (i.e., intersubjective validation). Validity in the first sense may be at odds with validity in the second, for example when a simple agreeable framing might be misleading given the uncertainty and complexity of the system behaviour. In sum, researchers seeking to manage the process of participatory modelling and its use may facilitate co-production by asking reflexive questions such as:
1. Who owns the process? Should the researcher-stakeholder relation be one of consultant-client or studyingstudied, or should they be co-management partners? The ethical and legal standards to adopt depend on which relation is assumed.

2. Who chooses the model/problem framing? What are suitable modelling platforms/options for a given context? How should researchers, as professionals, make comprehensive and usable toolboxes and frameworks available to stakeholders, going beyond promoting specific approaches of specific research groups?

3. Who is responsible for the validity of models? Can researchers be responsible for updating models beyond the project's time horizon? (adapted from Voinov and Bousquet 2010, Sect. 4.2).

\section{Assumptions about stake: reflexivity about interests and influences}

According to the third strategy (3.3), conflict is not inherently bad; it recognises that disputes and disagreements are inevitable. Conflict is detrimental only when it escalates to the level of destructive relations (Tropp 2015). Accordingly, the aim of reflexivity here is to encourage engagements across thought collectives that enable alternative perspectives to be heard in a non-destructive way. Managing conflict requires better understanding of assumptions of stake, including different types of interests and levels of influence. It necessarily requires a shift from social to 'societal' psychology, which considers not only individual differences but also the role of the media, political organisations, historical awareness and education processes (Reykowski 2015). Researchers seeking to manage the level of conflict can ask reflexive questions to promote 'cooperative independence' such as the following:

1. How can equal status between thought collectives be attained through institutional authorities, laws and customs? (Tropp 2015). For example, could this be achieved by changing the mechanisms through which knowledge is validated within and across thought collectives (Tengo et al. 2017)?

2. What strategies can be employed to enhance intergroup contact? For example, seeking out different opinions instead of avoiding them can build skills and resilience, which are needed in managing different opinions constructively (Böhm et al. 2020).

3. How can common identities between thought collectives be built? For example, how might recategorisation of the groups under one inclusive, superordinate category increase empathy, self-disclosure and acceptance (Dovidio and Banfield 2015)? Such an identity 
can be built, for example, on perceived interdependence (Dovidio et al. 2020).

We have argued that sustainability science's success in providing solutions for society depends on its capacity to understand and moderate normative tensions between thought collectives. In this section, responding to the recent calls for moving beyond merely 'more reflexivity' (Boström et al. 2017; Montana et al. 2020) in environmental sciences, we have provided a three-level typology of what type of reflexive research management is needed, focusing on how we should handle tensions across thought collectives in sustainability science. We can summarise some of the insights as follows: in specific modelling contexts, researchers' reflexivity revolves around assumptions underlying models and their ethical consequences (4.1). In broader problemframing contexts, researchers should reflect on their exact role in the process (4.2). In an open-ended space of thought collectives, tensions are not inherently bad but need to be contained by co-operative attitudes (4.3).

\section{Conclusions and future pathways for sustainability science}

Our current understanding of planetary boundaries requires a systemic and rapid shift in all sectors (McPhearson et al. 2021), and in ways that engage with academics, decisionmakers and citizens (Patterson et al. 2021). These shifts are highly complex and require new forms and systems of knowledge. A key question is, how can sustainability science navigate diverging views on sustainability solutions? To address this question, we have described a continuum of low-tech and high-tech collectives in the mobility and food sectors. In the mobility sector, the collectives diverge on whether the future of mobility should be based on leapfrogging development to autonomous vehicles that would be safer and more fuel-efficient, or whether cities should resort to integrated and densified urban planning that colocates activities to reduce mobility needs in general. In the food sector, a similar divergence between high- and low-tech collectives was observed between those supporting cellular agriculture and GMOs on the one hand, and those supporting traditional farming practices on the other. While the differences between the two collectives centre on sustainability solutions, there are deeper tensions between worldviews, values and methods at the heart of their discussions.

The divergent sustainability solutions between these collectives are rooted in disagreement over the valuation of risk, uncertainty and efficiency, as well as over fundamental values and views on nature, agency, ethics and justice. These tensions, if left unmanaged, threaten the viability of sustainability science as a problem-solving discipline. Against this background it is crucial to establish knowledge-system management strategies that have the potential to bridge the collectives and their divergent normative underpinnings, celebrating rather than ignoring divergences in interests or opinions across groups. Such bridging has promise in bringing forward sustainability solutions that are more legitimate and resilient compared to solutions developed in siloed thought collectives. We have put forward three strategies for managing the normative tensions between collectives: (1) common evaluative frameworks; (2) co-creation of knowledge geared towards practical problem-solving; and (3) accepting the complexity and plurality of values and facilitating a discerning discussion about values, interests, and stakes.

While all three strategies have utility in both mobility and food production, they also contain marked shortcomings limiting their application. Rather than offering clear-cut answers, we have established a set of reflexive questions to help sustainability scientists employ these three strategies and untangle normative tensions arising from their employment. Instead of emphasising the need for more reflexivity, or asserting who should be reflexive, we maintain that there are different kinds of reflexivity at play in the context of the three management strategies, necessitating a novel multilevel understanding of reflexivity.

Acknowledgements AIHM acknowledges EU funding through the Marie Sklodowska-Curie grant number 840207. The authors acknowledge the support of Helsinki Sustainability Science Institute which received funding from the Academy of Finland. NS acknowledges $\mathrm{UEF} / /$ Water programme and its funders Olvi Foundation, Saastamoinen Foundation and Wihuri Foundation. RT acknowledges Academy of Finland funded Centre of Excellence in Law, Identity and the European Narratives decision no. 336678.

Author contributions NS, CM and MN conceived the idea in a joint workshop with input from HT, LR, HT, AIHM, MSRM, CL and NK. $\mathrm{NS}, \mathrm{CM}$ and $\mathrm{MN}$ led the writing and revision process with input from HT, LR, HT, AIHM, MSRM, CL, SL, AV, RT and TM. HT and RM provided draft text for sections on food systems and LR, SL and CL on mobility systems. MN, MS and HT provided draft texts for the philosophical parts of the paper.

Funding Open access funding provided by University of Eastern Finland (UEF) including Kuopio University Hospital.

Open Access This article is licensed under a Creative Commons Attribution 4.0 International License, which permits use, sharing, adaptation, distribution and reproduction in any medium or format, as long as you give appropriate credit to the original author(s) and the source, provide a link to the Creative Commons licence, and indicate if changes were made. The images or other third party material in this article are included in the article's Creative Commons licence, unless indicated otherwise in a credit line to the material. If material is not included in the article's Creative Commons licence and your intended use is not permitted by statutory regulation or exceeds the permitted use, you will need to obtain permission directly from the copyright holder. To view a copy of this licence, visit http://creativecommons.org/licenses/by/4.0/. 


\section{References}

Alexander S, Yacoumis P (2018) Degrowth, energy descent, and 'lowtech' living: potential pathways for increased resilience in times of crisis. J Clean Prod 197(2):1840-1848

Anable J (2005) Complacent car addicts or aspiring environmentalists. Identifying travel behaviour segments using attitude theory. Transp Policy 12(1):65-78

Anagnostopoulou E, Urbančič J, Bothos E et al (2020) From mobility patterns to behavioural change: leveraging travel behaviour and personality profiles to nudge for sustainable transportation. J Intell Inf Syst 54:157-178

Anderson JM, Kalra N, Stanley KD, Sorensen P, Samaras C, Oluwatola OA (2016) Autonomous vehicle technology: a guide for policymakers. RAND Corporation, Santa Monica, CA

Arias-Arévalo P, Gómez-Baggethun E, Martín-López B, Pérez-Rincón M (2018) Widening the evaluative space for ecosystem services: a taxonomy of plural values and valuation methods. Environ Values 27(1):29-53

Arnette A, Zobel C, Bosch D, Pease J, Metcalfe T (2010) Stakeholder ranking of watershed goals with the vector analytic hierarchy process: effects of participant grouping scenarios. Environ Model Softw 25(11):1459-1469

Awad E, Dsouza S, Kim R, Schulz J, Henrich J, Shariff A, Rahwan I (2018) The moral machine experiment. Nature 563(7729):59-64

Baeten G (2000) The tragedy of the highway: empowerment, disempowerment and the politics of sustainability discourses and practices. Eur Plan Stud 8(1):69-86

Banister D (2011) Cities, mobility and climate change. J Transp Geogr 19(6):1538-1546

Barton DN, Bakken T, Madsen AL (2016) Using a Bayesian belief network to diagnose significant adverse effect of the EU Water Framework Directive on hydropower production in Norway. $\mathbf{J}$ Appl Water Eng Res 4(1):11-24. https://doi.org/10.1080/23249 676.2016.1178081

Bernstein JH (2015) Transdisciplinarity: a review of its origins, development, and current issues. J Res Practice 11:1-21

Bissell D (2018) Automation interrupted: how autonomous vehicle accidents transform the material politics of automation. Polit Geogr 65:57-66

Böhm I, Ferrari A, Woll SJN (2018) Visions of in vitro meat among experts and stakeholders. NanoEthics 12(3):211-224

Böhm R, Rusch H, Baron J (2020) The psychology of intergroup conflict: a review of theories and measures. J Econ Behav Organ 178:947-962. https://doi.org/10.1016/j.jebo.2018.01.020

Bonney R, Shirk JL, Phillips TB, Wiggins A, Ballard HL, Miller-Rushing AJ, Parrish JK (2014) Next steps for citizen science. Science 343(6178):1436-1437

Boström M, Lidskog R, Uggla Y (2017) A reflexive look at reflexivity in environmental sociology. Environ Sociol 3(1):6-16

Bothos E, Mentzas G, Prost S, Schrammel J, Röderer K (2014) Watch your emissions: persuasive strategies and choice architecture for sustainable decisions in urban mobility. Psychol J 12(3):107-126

Brewer GD (1999) The challenges of interdisciplinarity. Policy Sci $32: 327-337$

Brown K et al (2019) Empathy, place and identity interactions for sustainability. Glob Environ Chang 56:11-17

Burton S, Habli I, Lawton T, McDermid J, Morgan P, Porter Z (2020) Mind the gaps: assuring the safety of autonomous systems from an engineering, ethical, and legal perspective. Artif Intell 279:103-201

Cahill D, Humphrys E (2019) Rethinking the 'neoliberal thought collective' thesis. Globalizations 16(6):948-965
Campbell BM, Beare DJ, Bennett EM, Hall-Spencer JM, Ingram JS, Jaramillo F, Shindell D (2017) Agriculture production as a major driver of the Earth system exceeding planetary boundaries. Ecol Soc. https://doi.org/10.5751/ES-09595-220408

Campos VBG, Ramos RAR, de Miranda e Silva Correia, D. (2009) Multi-criteria analysis procedure for sustainable mobility evaluation in urban areas. J Adv Transp 43(4):371-390

Caniglia G, Luederitz C, von Wirth T, Fazey I, Martin-López B, Hondrila $\mathrm{K}$ et al (2021) A pluralistic and integrated approach to action-oriented knowledge for sustainability. Nat Sustain 4(2):93-100

Capra F, Luisi PL (2014) The systems view of life: a unifying vision. Cambridge University Press

Carney M (2012) "Food Security" and "Food Sovereignty": what frameworks are best suited for social equity in food systems? J Agric Food Syst Community Dev 2(2):71-87. https://doi.org/10. 5304/jafscd.2012.022.004

Casi, C., Guttorm, H. and Virtanen, P. (2021). Traditional Ecological Knowledge, in Parker, Krieg and Reetta Toivanen, Situating Sustainability A Handbook of Contexts and Concepts. Helsinki University Press. (forthcoming)

Chan KMA, Balvanera P, Benessaiah K, Chapman M, Díaz S, GómezBaggethun E, Gould R, Hannahs N, Jax K, Klain S, Luck GW, Martín-López B, Muraca B, Norton B, Ott K, Pascual U, Satterfield T, Tadaki M, Taggart J, Turner N (2016) Opinion: why protect nature? Rethinking values and the environment. PNAS 113(6):1462-1465

Chang R (2001) Value pluralism. In: Smelser NJ, Baltes PB (eds) International Encyclopedia of the social and behavioral sciences. Elsevier, New York, NY, pp 16139-16145

Chang H (2012) Is water H2O? Evidence, realism and pluralism, vol 293. Springer, Dordrecht

Chiles RM (2013) Intertwined ambiguities: meat, in vitro meat, and the ideological construction of the marketplace. J Consum Behav 12(6):472-482. https://doi.org/10.1002/cb.1447

Clark MA, Springmann M, Hill J, Tilman D (2019) Multiple health and environmental impacts of foods. Proc Natl Acad Sci 116(46):23357-23362

Claussmann L, O'Brien M, Glaser S, Najjaran H, Gruyer D (2018) Multi-criteria decision making for autonomous vehicles using fuzzy dempster-shafer reasoning, in 2018 IEEE Intelligent Vehicles Symposium IV, 2195-2202. IEEE

Collingwood L (2017) Privacy implications and liability issues of autonomous vehicles. Inf Commun Technol Law 26(1):32-45. https://doi.org/10.1080/13600834.2017.1269871

Creighton JL (2005) The public participation handbook: making better decisions through citizen involvement. John Wiley \& Sons

Creutzig F, Fernandez B, Haberl H, Khosla R, Mulugetta Y, Seto KC (2016) Beyond technology: demand-side solutions for climate change mitigation. Annu Rev Environ Resour 41:173-198

Dąbrowska P (2007) Civil society involvement in the EU regulations on GMOs: from the design of a participatory garden to growing trees of European public debate. J Civ Soc 3(3):287-304. https:// doi.org/10.1080/17448680701775788

De Luca AI, Iofrida N, Leskinen P, Stillitano T, Falcone G, Strano A, Gulisano G (2017) Life cycle tools combined with multicriteria and participatory methods for agricultural sustainability: insights from a systematic and critical review. Sci Total Environ 595:352-370

Dilworth T, McGregor A (2015) Moral steaks? Ethical discourses of in vitro meat in academia and Australia. J Agric Environ Ethics 28(1):85-107

Dovidio JF, Banfield JC (2015) Intergroup cooperation. In: Schroeder DA, Graziano W (eds) The Oxford handbook of prosocial behavior. Oxford University Press, pp 562-581 
Dovidio J, Ikizer E, Kunst J, Levy A (2020) Common identity and humanity. In: Jetten J, Reicher S, Haslam SA, Cruwys T (eds) Together apart: the psychology of COVID-19. Sage Publishing, pp 119-123

Duncan J, Claeys P (2018) Politicizing food security governance through participation: opportunities and opposition. Food Sec 10:1411-1424. https://doi.org/10.1007/s12571-018-0852-x

Esmail BA, Geneletti D (2018) Multi-criteria decision analysis for nature conservation: a review of 20 years of applications. Methods Ecol Evol 9(1):42-53

European Food Safety Agency 2005. https://www.efsa.europa.eu/ sites/default/files/event/documentset/3_terms_of_reference.pdf. Accessed 26 Nov 2021

Ewing R, Tian G, Lyons T, Terzano K (2017) Trip and parking generation at transit-oriented developments: five US case studies. Landsc Urban Plan 160:69-78

Fagnant DJ, Kockelman KM (2014) The travel and environmental implications of shared autonomous vehicles, using agent-based model scenarios. Transp Res Part C Emerg Technol 40:1-13

Fam D, Clarke E, Freeth R et al (2020) Interdisciplinary and transdisciplinary research and practice: balancing expectations of the 'old' academy with the future model of universities as 'problem solvers.' Higher Educ Q 74:19-34. https://doi.org/10.1111/hequ. 12225

FAO (2018) Transforming food and agriculture to achieve the SDGs. United Nations, Rome

Fazey I, Schäpke N, Caniglia G, Hodgson A, Kendrick I, Lyon C, Saha P (2020) Transforming knowledge systems for life on Earth: visions of future systems and how to get there. Energy Res Soc Sci 70:101724

Fleck L (1979) Genesis and development of a scientific fact. The University of Chicago Press

Fraedrich E, Heinrichs D, Bahamonde-Birke FJ, Cyganski R (2019) Autonomous driving, the built environment and policy implications. Transp Res Part A Policy Practice 122:162-172

Frantzeskaki N, Kabisch N (2016) Designing a knowledge co-production operating space for urban environmental governance-Lessons from Rotterdam, Netherlands and Berlin, Germany. Environ Sci Policy 62:90-98

Frantzeskaki N, Hölscher K, Bach M, Avelino F (2018) Co-creating sustainable urban futures. A primer on applying transition management in cities, Future City, 11

Frantzeskaki N, McPhearson T, Collier MJ, Kendal D, Bulkeley H, Dumitru A, Pintér L (2019) Nature-based solutions for urban climate change adaptation: linking science, policy, and practice communities for evidence-based decision-making. Bioscience 69(6):455-466

Funtowicz SO, Ravetz JR (1993) Science for the post-normal age. Futures 25(7):739-755

Gallo M, Marinelli M (2020) Sustainable mobility: a review of possible actions and policies. Sustainability 12(18):7499. https://doi.org/ $10.3390 /$ su 12187499

Gehl J (2010) Cities for people. Island Press

Gulsrud NM, Raymond CM, Rutt RL, Olafsson AS, Plieninger T, Sandberg M, Beery TH, Jönsson I (2018) 'Rage against the machine'? The opportunities and risks concerning the automation of urban green infrastructure. Landsc Urban Planning 180:85-92

Hacking I (2002) Inaugural lecture: Chair of Philosophy and History of Scientific Concepts at the Collège de France, 16 January 2001. Econ Soc 31(1): 1-14. https://doi.org/10.1080/030851401201092 22

Haider LJ, Hentati-Sundberg J, Giusti M, Goodness J, Hamann M, Masterson VA, Sinare H (2018) The undisciplinary journey: early-career perspectives in sustainability science. Sustain Sci 13(1):191-204
Hazard L, Cerf M, Lamine C, Magda D, Steyaert P (2019) A tool for reflecting on research stances to support sustainability transitions. Nat Sustain 3:89-95. https://doi.org/10.1038/s41893-019-0440-x

Hickman R, Banister D (2014) Transport, climate change and the city. Routledge

Hickman R, Seaborn C, Headicar P, Banister D, Swain C (2010) Spatial planning for sustainable transport? Town Ctry Planning 79(2):77-82

Himes A, Muraca B (2018) Relational values: the key to pluralistic valuation of ecosystem services. Curr Opin Environ Sustain 35:1-7

Huang H, De Smet Y, Macharis C, Doan NAV (2021) Collaborative decision-making in sustainable mobility: identifying possible consensuses in the multi-actor multi-criteria analysis based on inverse mixed-integer linear optimization. Int J Sust Dev World 28(1):64-74. https://doi.org/10.1080/13504509.2020.1795005

Intemann K (2015) Distinguishing between legitimate and illegitimate values in climate modelling. Euro Jnl Phil Sci 5:217-232. https:// doi.org/10.1007/s13194-014-0105-6

IPCC (2018) Global warming of $1.5^{\circ} \mathrm{C}$. An IPCC Special Report on the impacts of global warming of $1.5^{\circ} \mathrm{C}$ above pre-industrial levels and related global greenhouse gas emission pathways, in the context of strengthening the global response to the threat of climate change, sustainable development, and efforts to eradicate poverty [V. Masson-Delmotte, P. Zhai, H. O. Pörtner, D. Roberts, J. Skea, P.R. Shukla, A. Pirani, W. Moufouma-Okia, C. Péan, R. Pidcock, S. Connors, J. B. R. Matthews, Y. Chen, X. Zhou, M. I. Gomis, E. Lonnoy, T. Maycock, M. Tignor, T. Waterfield (eds.)]

Isaksson K, Richardson T (2009) Building legitimacy for risky policies: the cost of avoiding conflict in Stockholm. Transp Res Part A Policy Practice 43(3):251-257

Jasanoff S, Kim SH (2015) Dreamscapes of modernity: sociotechnical imaginaries and the fabrication of power. University of Chicago Press

Jeswani HK, Hellweg S, Azapagic A (2018) Accounting for land use, biodiversity and ecosystem services in life cycle assessment impacts of breakfast cereals. Sci Total Environ 645:51-59

Justus J et al (2009) Buying into conservation: intrinsic versus instrumental value. Trends Ecol Evol 24(4):187-191

Kitchin R, Coletta C, McArdle G (2017) Urban informatics, governmentality and the logics of urban control, The Programmable City Working Paper 25

Kläy A, Zimmermann AB, Schneider F (2015) Rethinking science for sustainable development: reflexive interaction for a paradigm transformation. Futures 65:72-85

Klein JT (1990) Interdisciplinarity: History, theory, and practice. Wayne state University Press

Klein JT (2010) A taxonomy of interdisciplinarity. In: Frode-man R, Klein JT, Mitcham C (eds) The Oxford handbook of Interdisciplinarity. Oxford University Press, pp 15-30

Koopman P, Wagner M (2017) Autonomous vehicle safety: an interdisciplinary challenge. IEEE Intell Transp Syst Mag 9(1):90-96

Koppelmäki K et al (2019) Ecological intensification by integrating biogas production into nutrient cycling: modeling the case of Agroecological symbiosis. Agric Syst 170:39-48

Kremer P, Hamstead ZA, McPhearson T (2016) The value of urban ecosystem services: a spatially explicit multicriteria analysis of landscape scale valuation scenarios in NYC. Environ Sci Policy (special Issue). https://doi.org/10.1016/j.envsci.2016.04.012

Krieg P, Toivanen R (2021) Situating sustainability. In: Krieg CP, Toivanen $\mathrm{R}$ (eds) A handbook of contexts and concepts. Helsinki University Press, Helsinki. https://doi.org/10.33134/HUP-14-1

Kronenberg J, Andersson E (2019) Integrating social values with other value dimensions: parallel use vs. combination vs. full integration. Sustain Sci 14(5):1283-1295. https://doi.org/10.1007/ s11625-019-00688-7 
Kuhn T (1962) The structure of scientific revolutions. University of Chicago Press

Lahsen M, Turnhout E (2021) How norms, needs, and power in science obstruct transformations towards sustainability. Environ Res Lett 16:025008

Lang DJ, Wiek A, Bergmann M, Stauffacher M, Martens P, Moll P, Thomas CJ (2012) Transdisciplinary research in sustainability science: practice, principles, and challenges. Sustain Sci $7(1): 25-43$

Langemeyer J, Gómez-Baggethun E, Haase D, Scheuer S, Elmqvist T (2016) Bridging the gap between ecosystem service assessments and land-use planning through Multi-Criteria Decision Analysis (MCDA). Environ Sci Policy 62:45-56. https://doi.org/10.1016/j. envsci.2016.02.013

Langemeyer J, Wedgwood D, McPhearson T, Baró F, Madsen AL, Barton DN (2020) Creating urban green infrastructure where it is needed-A spatial ecosystem service-based decision analysis of green roofs in Barcelona. Sci Total Environ 707:135487. https:// doi.org/10.1016/j.scitotenv.2019.135487

Longhurst N, Chilvers J (2019) Mapping diverse visions of energy transitions: co-producing sociotechnical imaginaries. Sustain Sci 14(4):973-990. https://doi.org/10.1007/s11625-019-00702-y

Lynam T, de Jong W, Shell D, Kusumanto T, Evans K (2007) A review of tools for incorporating community knowledge, preferences, and values into decision making in natural resources management. Ecol Soc. https://doi.org/10.5751/ES-01987-120105

Lyons G (2018) Getting smart about urban mobility-Aligning the paradigms of smart and sustainable. Transp Res Part A 115:4-14

Mace GM (2014) Whose conservation? Science 345(6204):1558-1560

Macharis C, Baudry G (2018) Decision-making for sustainable transport and mobility: multi actor multi criteria analysis. Edward Elgar Publishing

Majer JM et al (2021) Resolving conflicts between people and over time in the transformation toward sustainability: a framework of interdependent conflicts. Front Psychol. https://doi.org/10.3389/ fpsyg. 2021.623757

Marcu A, Gaspar R, Rutsaert P, Seibt B, Fletcher D, Verbeke W, Barnett J (2015) Analogies, metaphors, and wondering about the future: lay sense-making around synthetic meat. Public Underst Sci 24(5):547-562

Martens K (2016) Transport justice: designing fair transportation systems. Routledge

Mason E (2015) Value pluralism, in E.N. Zalta (ed), The Stanford Encyclopedia of Philosophy. Updated Summer 2015. Online at: http://plato.stanford.edu/archives/sum2015/entries/value-plura lism. Accessed 26 Nov 2021

Matuk FA, Turnhout E, Fleskens L, do Amaral EF, Haverroth M, Behagel JH (2020) Allying knowledge integration and co-production for knowledge legitimacy and usability: the Amazonian SISA policy and the Kaxinawá Indigenous people case. Environ Sci Policy 112:1-9

Mazac R, Tuomisto HL (2020) The post-anthropocene diet: navigating future diets for sustainable food systems. Sustainability 12(6):2355

McPhearson T, Raymond C, Gulsrud N, Albert C, Coles N, Fagerholm N, Vierikko K (2021) Radical changes are needed for transformations to a good Anthropocene. Npj Urban Sustain. https://doi.org/ 10.1038/s42949-021-00017-x

Meurs H, Haaijer R (2001) Spatial structure and mobility. Transp Res Part D Transp Environ 6(6):429-446. https://doi.org/10.1016/ S1361-9209(01)00007-4

Milakis D, van Arem B, van Wee B (2017) Policy and society related implications of automated driving: a review of literature and directions for future research. J Intell Transp Syst 21(4):324-348. https://doi.org/10.1080/15472450.2017.1291351
Miller J (2012) In vitro meat: power, authenticity and vegetarianism. J Crit Anim Stud 10(4):41-63

Miller TR, Muñoz-Erickson T, Redman CL (2011) Transforming knowledge for sustainability: towards adaptive academic institutions. Int J Sustain High Educ 12(2):177-192. https://doi.org/ $10.1108 / 14676371111118228$

Mitchell SD (2002) Integrative pluralism. Biol Philos 17(1):55-70

Mitchell SD (2009) Unsimple truths: science, complexity, and policy. University of Chicago Press

Mladenović MN (2019) How should we drive self-driving vehicles? Anticipation and collective imagination in planning mobility futures. In: Finger M, Audouin M (eds) The governance of smart transportation systems. The urban book series. Springer, Cham. https://doi.org/10.1007/978-3-319-96526-0_6

Mladenović MN, Leviäkangas P, Roncoli C et al (2020) Rethinking transport- towards clean and inclusive mobility (Highlights of the 2020 Transport Research Arena conference). Eur Transp Res Rev. https://doi.org/10.1186/s12544-020-00434-6

Mladenovic MN, McPherson T (2016) Engineering social justice into traffic control for self-driving vehicles? Sci Eng Ethics 22:11311149. https://doi.org/10.1007/s11948-015-9690-9

Mohorčich J (2020) Energy intensity and human mobility after the anthropocene. Sustainability 12:2376

Montana J, Elliott L, Ryan M, Wyborn C (2020) The need for improved reflexivity in conservation science. Environ Conserv 47(4):217-219

Mooney PH, Hunt SA (2009) Food security: the elaboration of contested claims to a consensus frame. Rural Sociol 74:469-497. https://doi.org/10.1111/j.1549-0831.2009.tb00701.x

Muldoon-Smith K, McGuinness D (2020) Tacit domains: the transference of practitioner know-how in contemporary English planning practice. Area 00:1-8. https://doi.org/10.1111/area.12641

Nikolaeva A, Adey P, Cresswell T, Lee JY, Nóvoa A, Temenos C (2019) Commoning mobility: towards a new politics of mobility transitions. Trans Inst Br Geogr 44(2):346-360

Nordhaus WD, Boyer J (2000) Warming the world: economic models of global warming. MIT press

Nordhaus WD (2017) Revisiting the social cost of carbon. Proc Natl Acad Sci 114(7):1518-1523

Norström AV et al (2020) Principles for knowledge co-production in sustainability research. Nat Sustain 3(3):182-190

Norton BG (2015) Sustainable values, sustainable change: a guide to environmental decision making. University of Chicago Press

Norton BG (2017) A situational understanding of environmental values and evaluation. Ecol Econ 138:242-248

O'Connor S, Kenter JO (2019) Making intrinsic values work; integrating intrinsic values of the more-than-human world through the Life Framework of Values. Sustain Sci 14:1247-1265. https:// doi.org/10.1007/s11625-019-00715-7

O’Neill J, Holland A, Light A (2008) Environmental values. Routledge, New York, NY

Osborne P (2015) Problematizing disciplinarity, transdisciplinary problematics. Theor Cult Soc 32(5-6):3-35. https://doi.org/10.1177/ 0263276415592245

Parodi A, Leip A, De Boer IJM, Slegers PM, Ziegler F, Temme EHM, Herrero M, Tuomisto H, Valin H, Van Middelaar CE, Van Loon JJA, Van Zanten HHE (2018) The potential of future foods for sustainable and healthy diets. Nat Sustain 1(12):782-789. https:// doi.org/10.1038/s41893-018-0189-7

Pascual U, Adams WM, Díaz S et al (2021) Biodiversity and the challenge of pluralism. Nat Sustain 4:567-572. https://doi.org/10. 1038/s41893-021-00694-7

Patterson J et al (2021) Finding feasible action towards urban transformations. NPJ Urban Sustain. https://doi.org/10.1038/ s42949-021-00029-7 
Penmetsa P, Adanu EK, Wood D, Wang T, Jones SL (2019) Perceptions and expectations of autonomous vehicles-A snapshot of vulnerable road user opinion. Technol Forecast Soc Chang 143:9-13

Pohl C, Wuelser G (2019) Methods for coproduction of knowledge among diverse disciplines and stakeholders. In: Hall K, Vogel A, Croyle R (eds) Strategies for team science success. Springer, Cham. https://doi.org/10.1007/978-3-030-20992-6_8

Poore J, Nemecek T (2018) Reducing food's environmental impacts through producers and consumers. Science 360(6392):987-992

Popa F, Guillermin M, Dedeurwaerdere T (2015) A pragmatist approach to transdisciplinarity in sustainability research: from complex systems theory to reflexive science. Futures 65:45-56

Raymond CM et al (2013) Ecosystem services and beyond: using multiple metaphors to understand human-environment relationships. Bioscience 63(7):536-546

Reykowski J (2015) Intractable conflicts-how can they be solved? The theory of Daniel Bar-Tal. The social psychology of intractable conflicts. Springer, Cham, pp 3-16

Sagaris L (2018) Citizen participation for sustainable transport: lessons for change from Santiago and Temuco, Chile. Res Transp Econ 69:402-410

Myers SS, Smith MR, Guth S, Golden CD, Vaitla B, Mueller ND, Dangour AD, Huybers P (2017) Climate change and global food systems: potential impacts on food security and undernutrition. Ann Rev Public Health 38(1):259-277

Pindyck RS (2013) Climate change policy: what do the models tell us? J Econ Lit 51(3):860-872

Pindyck RS (2017) The use and misuse of models for climate policy. Rev Environ Econ Policy 11(1):100-114. https://doi.org/10. 1093/reep/rew012

Popkin BM (2006) Global nutrition dynamics: the world is shifting rapidly toward a diet linked with noncommunicable diseases. Am J Clin Nutr 84(2):289-298. https://doi.org/10.1093/ajcn/84.2.289

Schäpke N, Stelzer F, Caniglia G, Bergmann M, Wanner M, SingerBrodowski M, Lang DJ (2018) Jointly experimenting for transformation? Shaping real-world laboratories by comparing them. GAIA-Ecol Perspect Sci Soc 27(1):85-96

Schipper F, Emanuel M, Oldenziel R (2020) Sustainable urban mobility in the present, past, and future. Technolo Cult 61(1):307-317. https://doi.org/10.1353/tech.2020.0004

Scoones I (2016) The politics of sustainability and development. Annu Rev Environ Resour 41:293-319

Sheller M (2004) Automotive emotions: feeling the car. Theory Cult Soc 21(4-5):221-242

Sheller M (2018) Mobility justice: the politics of movement in an age of extremes. Verso. https://doi.org/10.1068/d324t

Shoup DC (2005) The high cost of free parking. Planners Press, Chicago

Singh S (2015) Critical reasons for crashes investigated in the National Motor Vehicle Crash Causation Survey. Traffic Safety Facts Crash - Stats. Report No. DOT HS 812 115. National Highway Traffic Safety Administration, Washington, DC

Smyth SJ, Phillips PW, Castle D (2017) (Mis) information and the politicization of food security. Anim Front 7(2):33-38. https:// doi.org/10.2527/af.2017.0116

Spaargaren G, Oosterveer P, Loeber A (2011) Sustainability transitions in food consumption, retail and production. In: Spaargaren G, Oosterveer P, Loeber A (eds) Food practices in transition: changing food consumption, retail and production in the age of reflexive modernity. Routledge

Sparrow R, Howard M (2020) Make way for the wealthy? Autonomous vehicles, markets in mobility, and social justice. Mobilities 15(4):514-526

Springmann M, Charles H, Godfray J, Rayner M, Scarborough P (2016) Analysis and valuation of the health and climate change cobenefits of dietary change. PNAS 113(15):4146-4151
Stepanova O, Polk M, Saldert H (2020) Understanding mechanisms of conflict resolution beyond collaboration: an interdisciplinary typology of knowledge types and their integration in practice. Sustain Sci 15:263-279

Stirling A (2010) Keep it complex. Nature 468:1029-1031

Suddaby R, Viale T, Gendron Y (2016) Reflexivity: the role of embedded social position and entrepreneurial social skill in processes of field level change. Res Organ Behav 36:225-245. https://doi. org/10.1016/j.riob.2016.02.001

Sustar H, Mladenović MN, Givoni M (2020) The landscape of envisioning and speculative design methods for sustainable mobility futures. Sustainability 12(6): 2447

Taylor B, Chapron G, Kopnina H, Orlikowska E, Gray J, Piccolo JJ (2020) The need for ecocentrism in biodiversity conservation. Conserv Biol 34:1089-1096

Tengö M, Hill R, Malmer P, Raymond CM, Spierenburg M, Danielsen F, Folke C (2017) Weaving knowledge systems in IPBES, CBD and beyond-lessons learned for sustainability. Curr Opin Environ Sustain 26:17-25

Thomopoulos N, Givoni M (2015) The autonomous car-a blessing or a curse for the future of low carbon mobility? An exploration of likely vs. desirable outcomes. Eur J Futures Res. https://doi.org/ 10.1007/s40309-015-0071-z

Tilman D, Balzer C, Hill J, Befort BL (2011) Global food demand and the sustainable intensification of agriculture. PNAS 108(50):20260-20264

Timms P, Tight M, Watling D (2014) Imagineering mobility: constructing utopias for future urban transport. Environ Plan A 2014(46):78-93

Tropp L (2015) Dismantling an ethos of conflict: strategies for improving intergroup relations. In: Halperin E, Sharvit K (eds) The social psychology of intractable conflicts, peace psychology book series, vol 27. Springer

Tuomisto HL (2019) Vertical farming and cultured meat: immature technologies for urgent problems. One Earth 1(3):275-277

Tuomisto HL, Scheelbeek P, Chalabi Z, Ezzati M, Green R, Haines A, Myers SS, Smith R, Dangour AD (2017) Effects of environmental change on agriculture, nutrition and health: a framework with a focus on fruits and vegetables. Wellcome Open Res 2:21

Turnhout E, Metze T, Wyborn C, Klenk N, Louder E (2020) The politics of co-production: participation, power, and transformation. Curr Opin Environ Sustain 42:15-21. https://doi.org/10.1016/j. cosust.2019.11.009

Valles SA, Piso Z, O'Rourke M (2019) Coupled ethical-epistemic analysis as a tool for environmental science. Ethics Policy Environ 22(3):267-286. https://doi.org/10.1080/21550085.2019.1652288

van Breda J, Swilling M (2019) The guiding logics and principles for designing emergent transdisciplinary research processes: learning experiences and reflections from a transdisciplinary urban case study in Enkanini informal settlement, South Africa. Sustain Sci 14:823-841

van der Werf HM, Knudsen MT, Cederberg C (2020) Towards better representation of organic agriculture in life cycle assessment. Nat Sustain 3(6):419-425

Verlinghieri E (2020) Learning from the grassroots: a resourcefulnessbased worldview for transport planning. Transp Res Part A Policy Practice 133:364-377

Vezér M, Bakker A, Keller K et al (2018) Epistemic and ethical tradeoffs in decision analytical modelling. Clim Chang 147:1-10. https://doi.org/10.1007/s10584-017-2123-9

Voinov A, Bousquet F (2010) Modelling with stakeholders. Environ Model Softw 25(11):1268-1281

Voinov A, Kolagani N, McCall MK, Glynn PD, Kragt ME, Ostermann FO, Pierce SA, Ramu P (2016) Modelling with stakeholdersNext generation. Environ Model Softw 77:196-220. https://doi. org/10.1016/j.envsoft.2015.11.016 
Voinov A, Jenni K, Gray S, Kolagani N, Glynn PD, Bommel P, Prell C, Zellner M, Paolisso M, Jordan R, Sterling E, Schmitt Olabisi L, Giabbanelli PJ, Sun Z, Le Page C, Elsawah S, BenDor TK, Hubacek K, Laursen BK, Smajgl A (2018) Tools and methods in participatory modeling: Selecting the right tool for the job. Environ Model Softw 109:232-255. https://doi.org/10.1016/j. envsoft.2018.08.028

von Wehrden H, Guimarães MH, Bina O, Varanda M, Lang DJ, John B, Gralla F, Alexander D, Raines D, White A, Lawrence RJ (2019) Interdisciplinary and transdisciplinary research: finding the common ground of multi-faceted concepts. Sustain Sci 14:875-888. https://doi.org/10.1007/s11625-018-0594-X

Wadud Z, MacKenzie D, Leiby P (2016) Help or hindrance? The travel, energy and carbon impacts of highly automated vehicles. Transp Res Part A Policy Practice 86:1-18. https://doi.org/10.1016/j. tra.2015.12.001

Wallace KJ, Jago M, Pannell DJ, Kim MK (2021) Wellbeing, values, and planning in environmental management. J Environ Manage 277:111447

Washbourne C-L et al (2020) Improving collaboration between ecosystem service communities and the IPBES science-policy platform. Ecosyst People 16(1):165-174. https://doi.org/10.1080/26395 916.2020.1766573

Wiek A, Withycombe L, Redman CL (2011) Key competencies in sustainability: a reference framework for academic program development. Sustain Sci 6:203-218. https://doi.org/10.1007/ s11625-011-0132-6

Wiek A, Farioli F, Fukushi K, Yarime M (2012) Sustainability science: bridging the gap between science and society. Sustain Sci 7(Supplement 1):1-4. https://doi.org/10.1007/s11625-011-0154-0

Willett W, Rockström J, Loken B, Springmann M, Lang T, Vermeulen S et al (2019) Food in the Anthropocene: the EAT-Lancet
Commission on healthy diets from sustainable food systems. Lancet Comm 393(10170):447-492

Williams E, Das V, Fisher A (2020) Assessing the sustainability implications of autonomous vehicles: recommendations for research community practice. Sustainability 2020(12):1902. https://doi. org/10.3390/su12051902

Winsberg E (2018) Communicating uncertainty to policymakers: the ineliminable role of values. Climate Modelling. Palgrave Macmillan, Cham, pp 381-412

Wittmayer JM, Schäpke N (2014) Action, research and participation: roles of researchers in sustainability transitions. Sustain Sci 9(4):483-496

Wittmayer JM et al (2020) Beyond instrumentalism: Broadening the understanding of social innovation in socio-technical energy systems. Energy Res Soc Sci 70:101689

World Health Organization. (2018). Global status report on road safety 2018: Summary (No. WHO/NMH/NVI/18.20), World Health Organization

Zafra-Calvo N, Balvanera P, Pascual U, Merçon J, Martín-López B, van Noordwijk M, Díaz S (2020) Plural valuation of nature for equity and sustainability: insights from the Global South. Global Environ Change 63:102115

Zhang J (2017) (Extended) Family car, filial consumer-citizens: becoming properly middle class in post-socialist South China. Modern China 43(1):36-65. https://doi.org/10.1177/0097700416645138

Publisher's Note Springer Nature remains neutral with regard to jurisdictional claims in published maps and institutional affiliations. 